\title{
MODEL OF CONVEYER WITH THE REGULABLE SPEED
}

\author{
O.M. Pihnastyi ${ }^{1}$, V.D. Khodusov ${ }^{2}$ \\ ${ }^{1}$ National Technical University Kharkiv Polytechnic Institute, Kharkov, Ukraine \\ ${ }^{2}$ Karazin Kharkiv National University, Kharkov, Ukraine \\ E-mail: pom7@bk.ru, khodusov@pht.univer.kharkov.ua
}

\begin{abstract}
This article is devoted to mathematical modelling of the production flow lines of the conveyor-type. Here is an analytical method for calculating the parameters of a production line with a regulated speed of the movement of the subjects of the labour along the conveyor developed. The description of the parameters of the state of the production line is made in the one-moment approximation using partial differential equations. There has been derived a solution that determines the state of the parameters of the production line for a given technological position as a function of the time. The transitional period during which the initial condition of the distributing of the subjects of the labour along a conveyor has the influence on the state parameters of a production line is certain. The developed method of the calculation of the flow parameters of the production line allows designing control systems of the production line of the conveyor-type with a regulated rate of the movement of the subjects of the labour.

Keywords: conveyor; a subject of labour; production line; PDE-model of the production; parameters of the state of the production line; technological position; transition period; production management systems.
\end{abstract}

\section{Introduction}

To model industrial systems with a flow-based method of the organising production, in the vast majority of the cases, four main types of models are using: discrete-event models (DES-model) [1], models of the queuing [2], the fluid model [3] and the PDE model $[4,5]$, that use the partial differential equations. A detailed comparative analysis of these models was done in the articles $[4,6,7]$. The PDE-models are most demand at the moment when designing control systems for flow lines that operate in transient modes or with variable capacity [8]. Production systems with a variable output of the products include in oneself some production systems that use the conveyor type of the organisation of the production (Fig. 1) [9-11]. It should also be noted that the PDE-models are very effectively used to describe the industrial production of semiconductor products [4-6], rolled steel [12]. In this paper, we will consider in detail the model of a conveyor line with a regulable speed using partial differential equations. The control of the speed of the belt of a separate conveyor changes the statistical characteristics of the flow at the output. It leads to a change in the amount of input flow on subsequent conveyors, which affects their power consumption [13]. Uneven loading of rock along the belt conveyor directly affects the transportation cost of the rock and determines the dynamics of the system as a whole. When designing the control systems of the conveyor, it is required to the planned normative volumes of the rock mining. In fact, in real production, the flow of the rock varies in time. These changes are very significant even during the daily period of the rock mining (Fig. 2) [14]. Fig. 2 demonstrates the percentage of the time, during which a conveyor works in one of several speed modes, certain relative speed $g=v / V_{n}$, where $v$ 

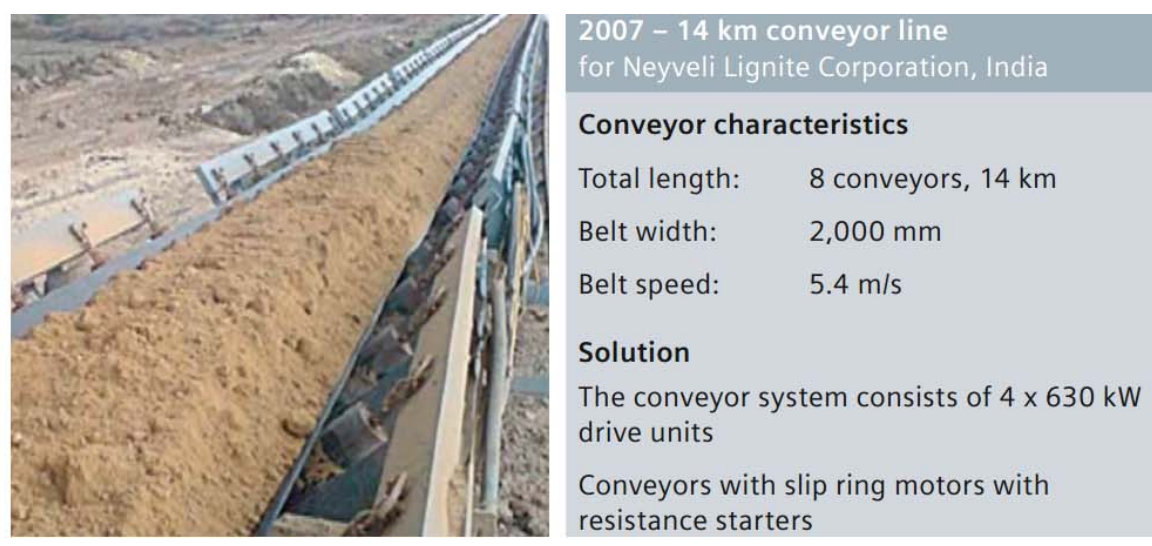

Fig. 1. Characteristics of the conveyor line Neyveli Lignite Corporation, India [9]

a)

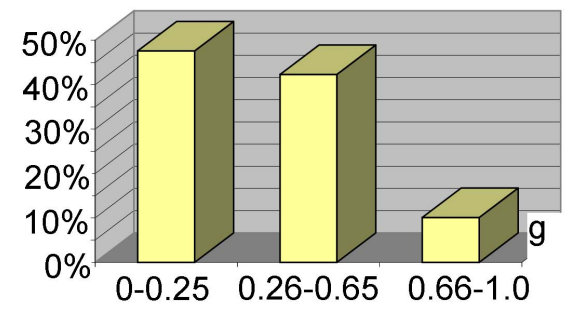

b)

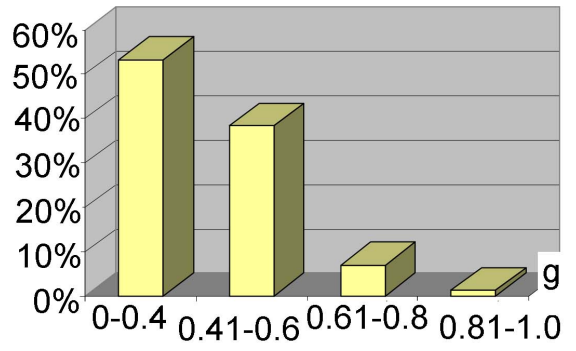

Fig. 2. Chart of a relative speed of the belt conveyer for a day long: a)mine WESTFALEN, Germany; b)mine KWK ANNA, Poland [14]

actual speed of the conveyor, $V_{n}$ is the maximally possible speed of the conveyor during the day. The speed of the conveyor belt should correspond to the level that ensures the optimum work of the conveyor line. The uneven distribution of the loaded rock along the length of the conveyor has a significant effect on the law control the speed of the conveyor. This effect consists in the fact that the process of the changing the speed of the conveyor belt is performed with a delay, the value of which is determined the linear density of the distribution the rock along the conveyor line. It can be assumed that the value of delay is proportional to the length of the conveyor and is inversely proportional to the speed of the belt. Although a large number of research on conveyor lines, the problem of regulating the speed of belt conveyors, which reduce energy consumption at transporting, is currently very actual [11]. Exclusive attention deserves the problem of the transport dependence and operating costs on changing the distributing of the rock load along the conveyor and the speed of the conveyor belt. In this regard, this article is devoted to the study of the distribution of the linear load of the rock along the conveyor on the speed of the conveyor belt.

\section{PDE-Model of the Production Line}

For investigating the parameters of conveyor lines the basic models are discrete-event models and queuing models $[10,11,13]$. These models are not effective for modelling production lines because they do not allow describing the distribution subjects of the labour along the production line $[4,7,8]$. For designing control systems for modern 
production lines, at the moment a new class of models uses - PDE-model [4-6]. PDEmodels take into account the stochastic nature of the interact of the technological equipment and the subject of labour during technological processing $[5,6,16]$ as well as their distribution by technological positions. We will consider the ideal production systems, which are characterised by the absence of loss of the subjects of the labour as a result of the production process (there are no defective products). The system of equations that determines the behaviour of the parameters of the production line in a one-moment description has the form [4, p. 70; 5, p. 4585]:

$$
\begin{gathered}
\frac{\partial[\chi]_{0}(\mathrm{t}, \mathrm{S})}{\partial t}+\frac{\partial[\chi]_{1}(\mathrm{t}, \mathrm{S})}{\partial S}=0 \\
{[\chi]_{1}(\mathrm{t}, \mathrm{S})=[\chi]_{1 \psi}(\mathrm{t}, \mathrm{S}), \quad[\chi]_{0}\left(\mathrm{t}_{0}, \mathrm{~S}\right)=\Psi(\mathrm{S}),}
\end{gathered}
$$

where $[\chi]_{0}(t, S)$ is the density of the distribution of the subjects of the labour by technological positions (WIP: work-in-progress); $[\chi]_{1 \psi}(\mathrm{t}, \mathrm{S})$ is the capacity of the processing of the subjects of the labour on a technological operation; $[\chi]_{1}(t, S)$ is the rate of processing of the subjects of the labour by technological positions at a time $t$. The position of the subject of the labour in the technological route is characterized by the coordinate $S \in\left(0 ; S_{d}\right)$. When using the coordinates of the cost space, $S_{d}$ corresponds the full self-cost of the product. The initial condition determines the number of the subjects of the labour at a time $t$ on each technological operation. The solution of the system of the equations (1),(2) allows us to calculate the parameters of the production line.

\section{PDE-Model of the Conveyor Line}

A widespread method of organizing a flow production is the use of conveyor lines with the variable speed of the belt movement $[10,11,13,14]$. A conveyor with a variable speed of the belt is used to reduce the costs of the transporting the rock (in the mines, $[10,11,13]$ ), as well as to synchronize the output of the product with the existing demand (in industrial enterprises, $[4,5])$. A characteristic feature of the modelling of the conveyor line for an industrial enterprise is that the subjects of the labour move along the conveyor with the same speed. Similarly, for mine conveyors, the rock transport speed at an arbitrary location of the conveyor is equal to the speed of the belt. In this connection, the system of equations describing the motion of the rock along the conveyor line has the form:

$$
\begin{gathered}
\frac{\partial[\chi]_{0}(\mathrm{t}, \mathrm{S})}{\partial t}+\frac{\partial[\chi]_{1}(\mathrm{t}, \mathrm{S})}{\partial S}=\delta(\mathrm{S}) \lambda(\mathrm{t}), \quad \int_{-\infty}^{\infty} \delta(S) d S=1, \\
{[\chi]_{1}(\mathrm{t}, \mathrm{S})=[\chi]_{0}(\mathrm{t}, \mathrm{S}) a(t), \quad[\chi]_{0}\left(\mathrm{t}_{0}, \mathrm{~S}\right)=\mathrm{H}(\mathrm{S}) \Psi(\mathrm{S}), \quad \mathrm{H}(\mathrm{S})= \begin{cases}0, & \text { if } S<0 ; \\
1, & \text { if } S \geqslant 0 .\end{cases} }
\end{gathered}
$$

The technological position with the coordinate $S=S_{d}$ corresponds to the degree of readiness of the subject of the labour, that is, the state to which the subject of the labour must correspond when leaving the conveyor line according to the production and technological documentation. Parameters $[\chi]_{0}(t, S)$ and $[\chi]_{1}(t, S)(4)$ are related each other by a coefficient $a=a(t)$ that determines the speed of the conveyor belt. For definiteness, 
we assume that the speed of the belt during the day has the form:

$$
a(t)=a_{0}-a_{1} \cos \left(2 \pi \frac{t}{T_{S}}\right), \quad a_{0}, a_{1} \geqslant 0, \quad a_{0}-a_{1}, \geqslant 0
$$

where $a_{0}$ is an average conveyor speed during the duration $T_{S}$ (e.g. during the day); $a_{1}$ is the amplitude of the change of the speed during the duration $T_{S}$. Here we consider the case where the speed of the conveyor at the start of the day is $\left.a(t)\right|_{t=n T_{S}}=a_{0}-a_{1}$, increases with the time and reaches the maximum value in the middle of the day $\left.a(t)\right|_{t=\left(n+\frac{1}{2}\right) T_{S}}=a_{0}+a_{1}$, then decreases to its start value $\left.a(t)\right|_{t=(n+1) T_{S}}=a_{0}-a_{1}$. The right side of the equation specifies the source of the supply of the rock on the first technological operation at the point with the coordinate $S=0$.

\section{PDE-Model of Conveyor Line in Dimensionless Form}

The state of flow parameters of the conveyor line will be described using dimensionless variables and parametrs

$$
\begin{gathered}
\tau=t / T_{d}, \quad \xi=S / S_{d}, \\
\mathrm{H}(\xi) \psi(\xi)=\frac{\mathrm{H}(\mathrm{S}) \Psi(\mathrm{S})}{\Theta}, \quad \gamma(\tau)=\frac{\lambda(\mathrm{t})}{\Theta} \frac{T_{d}}{S_{d}}, \quad g(\tau)=\frac{a(t) T_{d}}{S_{d}}, \\
\theta_{0}(\tau, \xi)=\frac{[\chi]_{0}(\mathrm{t}, \mathrm{S})}{\Theta}, \quad \Theta=\max \left\{\Psi(\mathrm{S}), \int_{t_{0}}^{t} \lambda(\eta) d \eta\right\} .
\end{gathered}
$$

Taking into account the notation introduced, we write down the balance equation (3) - (4) in the dimensionless form:

$$
\begin{gathered}
\frac{\partial \theta_{0}(\tau, \xi)}{\partial \tau}+g(\tau) \frac{\partial \theta_{0}(\tau, \xi)}{\partial \xi}=\delta(\xi) \gamma(\tau), \\
\theta_{0}\left(\tau_{0}, \xi\right)=\mathrm{H}(\xi) \psi(\xi) .
\end{gathered}
$$

We write for the system (16) the system of characteristic equations (9):

$$
\begin{gathered}
\frac{d \xi}{d \tau}=g(\tau),\left.\quad \xi\right|_{\tau=\tau_{0}}=æ, \\
\frac{d \theta_{0}(\tau, \xi)}{d \xi}=\delta(\xi) \frac{\gamma(\tau)}{g(\tau)},\left.\quad \theta_{0}\left(\tau_{0}, \xi\right)\right|_{\tau=\tau_{0}}=\theta_{0}\left(\tau_{0}, æ\right)=H(æ) \psi(æ) .
\end{gathered}
$$

The solution of the equation (11) can be written

$$
\begin{gathered}
\xi-\int g(\tau) d \tau-C_{1}=0, \quad \xi-G(\tau)-C_{1}=0, \quad \int g(\tau) d \tau=G(\tau), \quad C_{1}=\text { const } \\
\left.\xi\right|_{\tau=\tau_{0}}=æ \quad \Rightarrow \quad C_{1}=æ-G\left(\tau_{0}\right), \quad \xi=G(\tau)-G\left(\tau_{0}\right)+æ \quad \text { or } \quad \xi=\int_{t_{0}}^{t} g(\tau) d \tau+æ .
\end{gathered}
$$


We are going to express from the equation (13) the time $\tau$

$$
\tau=G^{-1}\left(\xi+G\left(\tau_{0}\right)-æ\right)
$$

and substitute the resulting expression in the equation (12). This will allow us to write

$$
\begin{gathered}
\theta_{0}(\tau, \xi)=\int \delta(\xi) \frac{\gamma(\tau)}{g(\tau)} d \xi+C_{2}=\int \delta(\xi) \frac{\gamma\left(G^{-1}\left(\xi+G\left(\tau_{0}\right)-æ\right)\right)}{g\left(G^{-1}\left(\xi+G\left(\tau_{0}\right)-æ\right)\right)} d \xi+C_{2}= \\
=\mathrm{H}(\xi) \frac{\gamma\left(G^{-1}\left(G\left(\tau_{0}\right)-æ\right)\right)}{g\left(G^{-1}\left(G\left(\tau_{0}\right)-æ\right)\right)}+C_{2}=\mathrm{H}(\xi) \frac{\gamma\left(G^{-1}(G(\tau)-\xi)\right)}{g\left(G^{-1}(G(\tau)-\xi)\right)}+C_{2}, \quad C_{2}=\text { const. }
\end{gathered}
$$

The integration constant $C_{2}$ is determined from the initial condition (12)

$$
\theta_{0}\left(\tau_{0}, æ\right)=H(æ) \frac{\gamma\left(G^{-1}\left(G\left(\tau_{0}\right)-æ\right)\right)}{g\left(G^{-1}(G(\tau)-æ)\right)}+C_{2}=H(æ) \psi(æ)
$$

where from

$$
C_{2}=H(æ) \psi(æ)-H(æ) \frac{\gamma\left(G^{-1}\left(G\left(\tau_{0}\right)-æ\right)\right)}{g\left(G^{-1}\left(G\left(\tau_{0}\right)-æ\right)\right)} .
$$

We substitute the obtained expression for the integration constant (16) in (12), obtain a solution for $(9)-(10)$

$$
\theta_{0}(\tau, \xi)=\mathrm{H}(\xi) \frac{\gamma\left(G^{-1}(G(\tau)-\xi)\right)}{g\left(G^{-1}(G(\tau)-\xi)\right)}-H(æ) \frac{\gamma\left(G^{-1}\left(G\left(\tau_{0}\right)-æ\right)\right)}{g\left(G^{-1}\left(G\left(\tau_{0}\right)-æ\right)\right)}+H(æ) \psi(æ)
$$

We can use (13) to represent the solution in the following form

$$
\begin{aligned}
\theta_{0}(\tau, \xi)= & \left(\mathrm{H}(\xi)-H\left(\xi-\int_{\tau_{0}}^{\tau} g(\tau) d \tau\right)\right) \frac{\gamma\left(G^{-1}(G(\tau)-\xi)\right)}{g\left(G^{-1}(G(\tau)-\xi)\right)}+ \\
& +H\left(\xi-\int_{\tau_{0}}^{\tau} g(\tau) d \tau\right) \psi\left(\xi-\int_{\tau_{0}}^{\tau} g(\tau) d \tau\right)
\end{aligned}
$$

The solution (18) satisfies the initial condition (10)

$$
\begin{gathered}
\theta_{0}\left(\tau_{0}, \xi\right)=\left(\mathrm{H}(\xi)-H\left(\xi-G\left(\tau_{0}\right)\right)\right) \frac{\gamma\left(G^{-1}\left(G\left(\tau_{0}\right)-\xi\right)\right)}{g\left(G^{-1}\left(G\left(\tau_{0}\right)-\xi\right)\right)}+\mathrm{H}(\xi) \psi(\xi)=\mathrm{H}(\xi) \psi(\xi), \\
\theta(\tau, 0)= \begin{cases}\gamma(\tau) / g(\tau), & \text { if } \tau>\tau_{0} \\
H(0) \psi(0), & \text { if } \tau=\tau_{0}\end{cases}
\end{gathered}
$$




\section{Analysis of the Solution}

We assume that the initial distribution of the rock along the conveyor line is given at the time $\tau_{0}=0$

$$
\theta(0, \xi)=\psi(\xi)=H(\xi)(1-\xi)
$$

The intensity of the arrival of the rock on the conveyor line is started at time $\tau_{0}=0$ and has a constant value

$$
\gamma(\tau)=H\left(\tau-\tau_{0}\right)=H(\tau)
$$

In accordance with the results of the research (Fig. 2, [14]), the conveyor speed is represented by a periodic function with a period $T_{S}=24$ hours:

$$
g(\tau)=g_{0}-g_{1} \cos \left(\omega_{S} \tau\right), \quad g_{0}=\frac{a_{0} T_{d}}{S_{d}}, \quad g_{1}=\frac{a_{1} T_{d}}{S_{d}}, \quad \tau_{S}=\frac{T_{S}}{T_{d}}, \quad \omega_{S}=\frac{2 \pi}{\tau_{S}} .
$$

The first integral (13) has the form

$$
\xi=G(\tau)-G\left(\tau_{0}\right)+æ, \quad G(\tau)=\mathrm{g}_{0} \tau-\frac{\mathrm{g}_{1}}{\omega_{\mathrm{S}}} \sin \left(\omega_{\mathrm{S}} \tau\right), \quad G(0)=0 .
$$

Taking (21) - (24) into account, the solution q can be written as follows

$$
\begin{aligned}
\theta_{0}(\tau, \xi)=\left(\mathrm{H}(\xi)-H\left(\xi-\mathrm{g}_{0} \tau+\frac{\mathrm{g}_{1}}{\omega_{\mathrm{S}}} \sin \left(\omega_{\mathrm{S}} \tau\right)\right)\right) \frac{\gamma\left(G^{-1}\left(\mathrm{~g}_{0} \tau-\frac{\mathrm{g}_{1}}{\omega_{\mathrm{S}}} \sin \left(\omega_{\mathrm{S}} \tau\right)-\xi\right)\right)}{g\left(G^{-1}\left(\mathrm{~g}_{0} \tau-\frac{\mathrm{g}_{1}}{\omega_{\mathrm{S}}} \sin \left(\omega_{\mathrm{S}} \tau\right)-\xi\right)\right)}+ \\
+H\left(\xi-\mathrm{g}_{0} \tau+\frac{\mathrm{g}_{1}}{\omega_{\mathrm{S}}} \sin \left(\omega_{\mathrm{S}} \tau\right)\right) \psi\left(\xi-\mathrm{g}_{0} \tau+\frac{\mathrm{g}_{1}}{\omega_{\mathrm{S}}} \sin \left(\omega_{\mathrm{S}} \tau\right)\right) .
\end{aligned}
$$

Let us determine the time of the transition period $T_{t r}$. If the working time of the conveyor line is longer than the duration of the transition period $\Delta \tau=\left(\tau-\tau_{0}\right) \geq T_{t r}$, then the solution (25) will not depend on the initial conditions (21). For a period of time equal to the duration of the transition period, all the rock that was on the conveyor belt will be unloaded from the conveyor

$$
\psi\left(1-\mathrm{g}_{0} \tau+\frac{\mathrm{g}_{1}}{\omega_{\mathrm{S}}} \sin \left(\omega_{\mathrm{S}} \tau\right)\right)=0, \text { when } \quad \Delta \tau=\left(\tau-\tau_{0}\right)=\tau \geq T_{t r} .
$$

The duration of the transition period is determined by solving equation

$$
1-g_{0} T_{p r}-\frac{g_{1}}{\omega_{S}} \sin \left(\omega_{S} T_{p r}\right)=0 .
$$

If $T_{d}>>T_{S}$, the transition period can estimate the next value $1-g_{0} T_{p r} \approx 0, \quad T_{p r} \approx 1 / g_{0}$. The distribution of the rock along the conveyor belt for the steady state is described by formula

$$
\theta_{0}(\tau, \xi)=g\left(G^{-1}\left(\mathrm{~g}_{0} \tau-\frac{\mathrm{g}_{1}}{\omega_{\mathrm{S}}} \sin \left(\omega_{\mathrm{S}} \tau\right)-\xi\right)\right)^{-1}, \quad \tau \geq T_{t r}
$$




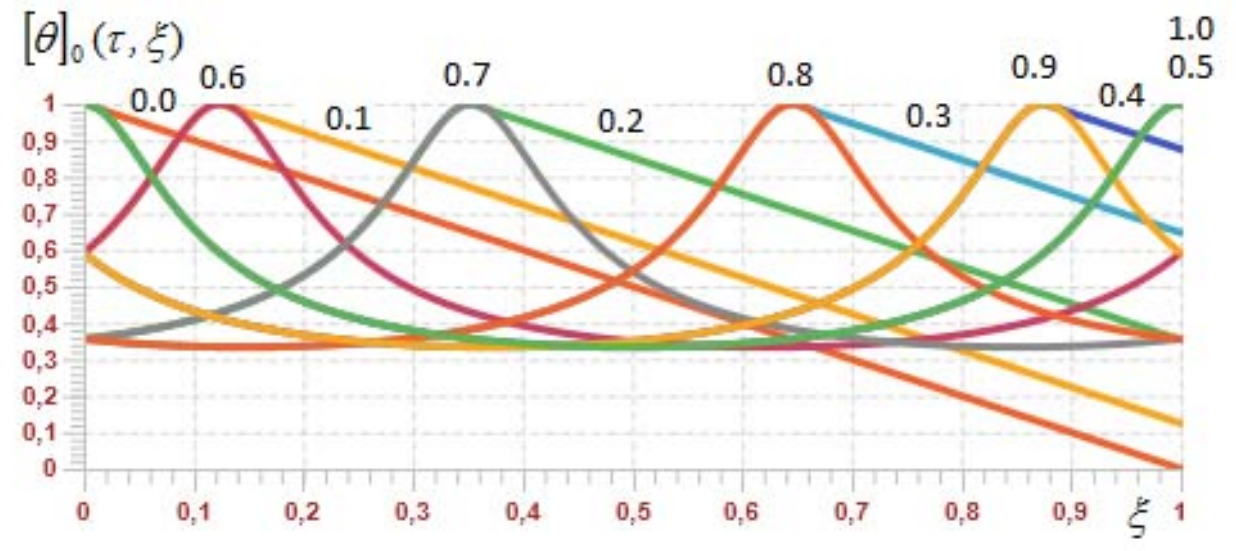

Fig. 3. Distribution of the rock along the conveyor for times $\tau=(0,0 ; 0,1 ; 0,2 ; \ldots ; 0,9 ; 1,0)$

Fig. 3 shows the solution for the parameters $g_{0}=2, g_{1}=1, \tau_{S}=0,5$ that determines the speed of the conveyor belt. A detailed representation, which clearly demonstrates the distribution of the rock along the conveyor belt for different times, is shown in Fig. 4 . The distribution of the rock at the initial time (Fig. 4.1) is determined by the initial condition (10). The distribution of the rock along the conveyor, shown in Figs. $4.1-4.5$, corresponds to the transient mode of the working of the conveyor line. For the conveyor operation times exceeding the duration of the transition period $T_{p r}$ (Figs. 4.6-4.10), the initial distribution does not participate in the formation of the distribution of the rock along the conveyor line. This corresponds to the steady state of the conveyors' work (28). For a steady state, a local accumulation of the rock with a period of $\tau_{S}$ is observed, which negatively affects the performance characteristics of the conveyor $[10,11,13]$. The dispersion of the distribution during a period is determined by the value of the variable component of the speed $g_{1}$, or more precisely by the relationship $g_{1} / g_{0}$. The distribution of the rock at times $\tau=(0,0 ; 0,1 ; 0,2 ; \ldots ; 0,5)$ is determined by the source of the rock input $(22)$ and the displacement of the initial distribution of the rock (21) along the conveyor line with the speed $g(\tau)$. Fig. 5 shows the values of the amount of rock for a particular technological position, which is determined by the coordinate $S$. A detailed representation determining the change in the unit density of the rock as a function of time for a certain technological position on the conveyor is shown in Fig. 6. Fig. 6.1 demonstrates the amount of rock in relation to the time that enters the conveyor line. This quantity is formed by the function of the intensity of the arrival of the rock $\lambda(\tau)(22)$, on the one hand, and the speed of the movement of the conveyor belt $g(\tau)(23)$, on the other hand. Fig. 6.10 shows the amount of the rock depending on the time that is shipped from the conveyor line. This is an important characteristic that determines the competitive ability of the production system [4-8]. This figure clearly demonstrates that the output flow of rock from the conveyor line is great extenting determined by the law of the speed of the movement of the conveyor belt. This is an important circumstance that should be taken into account when designing enterprise management systems with a flow-based method of the production organization. And this can be done using the PDE-model, as shown here. The speed control of the conveyor belt allows not only to save the resources used in the work of the conveyor, as correctly pointed out in $[10,11,13]$, but also makes it possible to obtain revenue by ensuring the fulfilment of the optimal portfolio of orders [4-8]. Also attention should be paid to the fact that the 

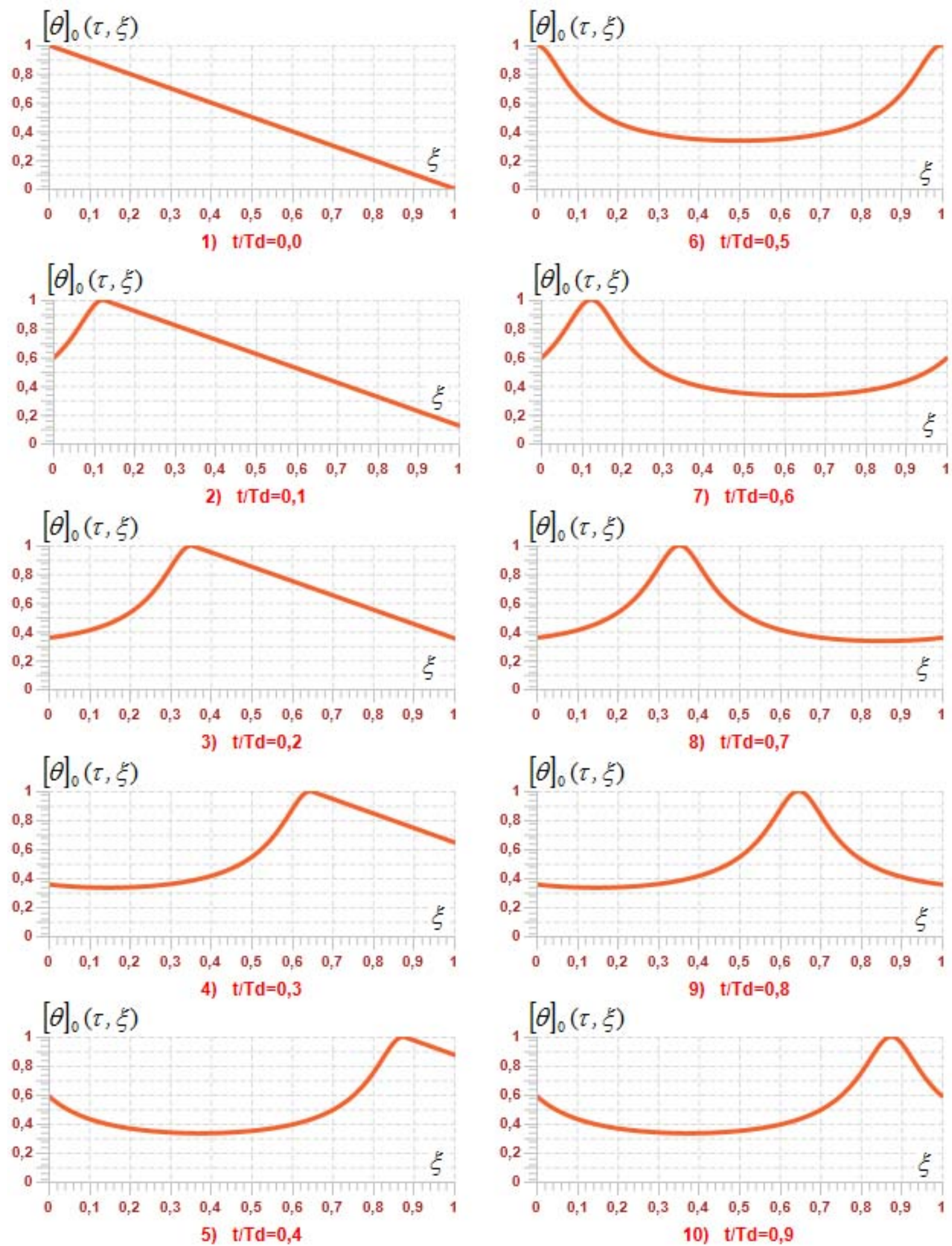

Fig. 4. Detailed representation of the distribution of the rock along the conveyor for times $\tau=(0,0 ; 0,1 ; 0,2 ; \ldots ; 0,9 ; 1,0)$ 


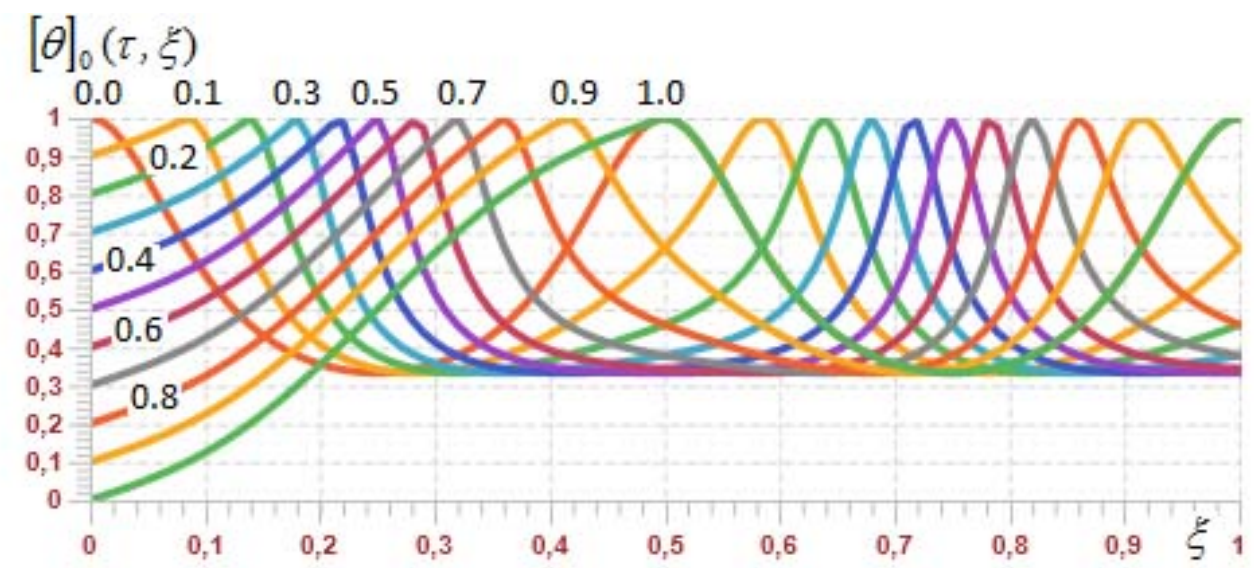

Fig. 5. Distribution of the rock along the conveyor for the technological position $S=(0,0 ; 0,1 ; 0,2 ; \ldots ; 0,9 ; 1.0)$

amount of the rock at the output is determined by its amount of the input with some delay, which is a function of the speed of the conveyor belt.

\section{Calculation of the Duration of the Production Cycle}

The duration of the production cycle is an important characteristic of the production system. Let us demonstrate the calculation of this characteristic below. The characteristic equation (24) determines the trajectories of the movement of individual objects along the technological route of the conveyor line (Fig. 7). As one would expect, the movement of a single object along the technological trajectory is carried out at a constant speed equal to the speed of the conveyor line. Equation (24) allows you to calculate the duration of the production cycle. The duration of the production cycle is equal to the time interval for which the object of labour passes the path from the first technological position to the last. Calculation of the duration of the production cycle for enterprises with a flow-method of organizing production is given in [16]. The value the duration of the production cycle for a conveyor-type production line can be defined as follows

$$
\tau_{d}=\int_{0}^{1} \frac{d \xi}{g(\tau)} .
$$

Products that arrived on the conveyor line at the time $\tau_{0}$, leave the conveyor line at time $\tau$ with a delay $\tau_{d}=\tau-\tau_{0}$. This delay is equal to the duration of the production cycle. The delay depends on the time at which the rock enters the conveyor, it is not constant value.

\section{Conclusions and Further Prospects of Development and Improvement of PDE-Models of Production Systems}

The obtained results of the research are basic for the development of control systems for the production of the conveyor type. It is shown that the distribution of the rock along the conveyor belt is determined by the speed of the conveyor belt. The influence of the 


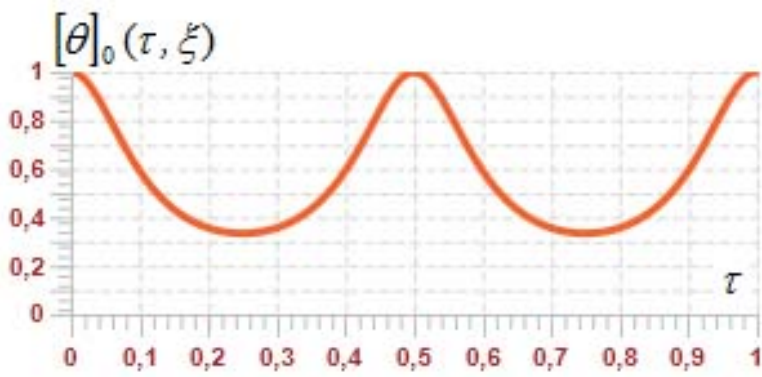

${ }_{1}[\theta]_{0}(\tau, \xi)$

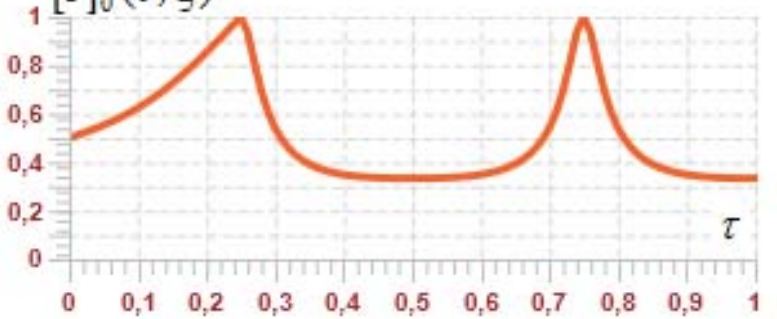

$[\theta]_{0}(\tau, \xi)$

1) $S / S d=0,0$

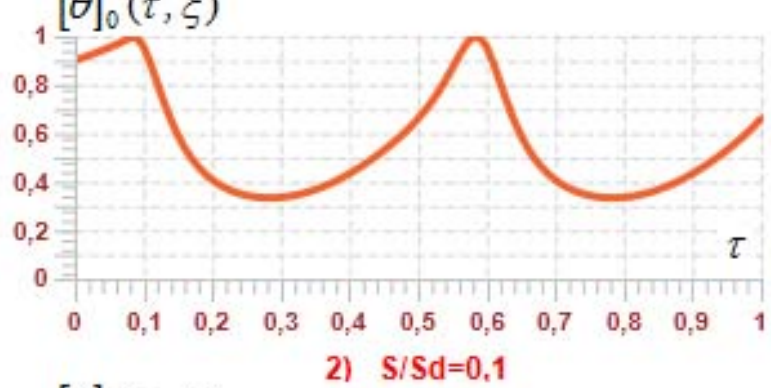

$[\theta\rceil_{0}(\tau, \xi)$

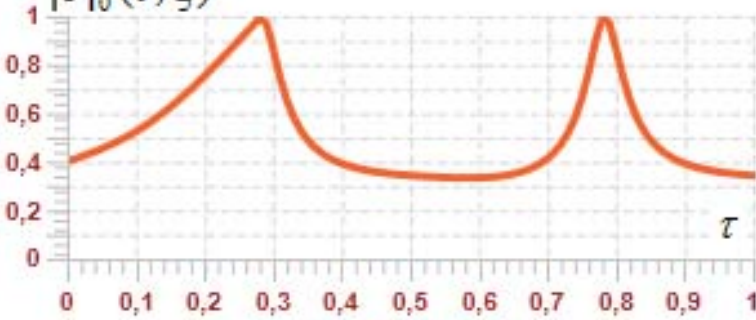

${ }_{1}[\theta]_{0}(\tau, \xi)$

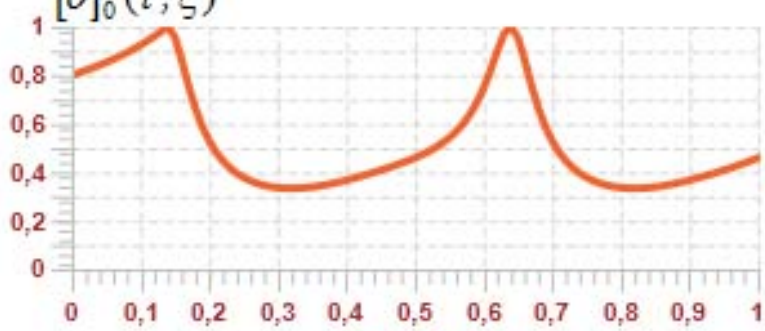

${ }_{1}[\theta\rceil_{0}(\tau, \xi)$
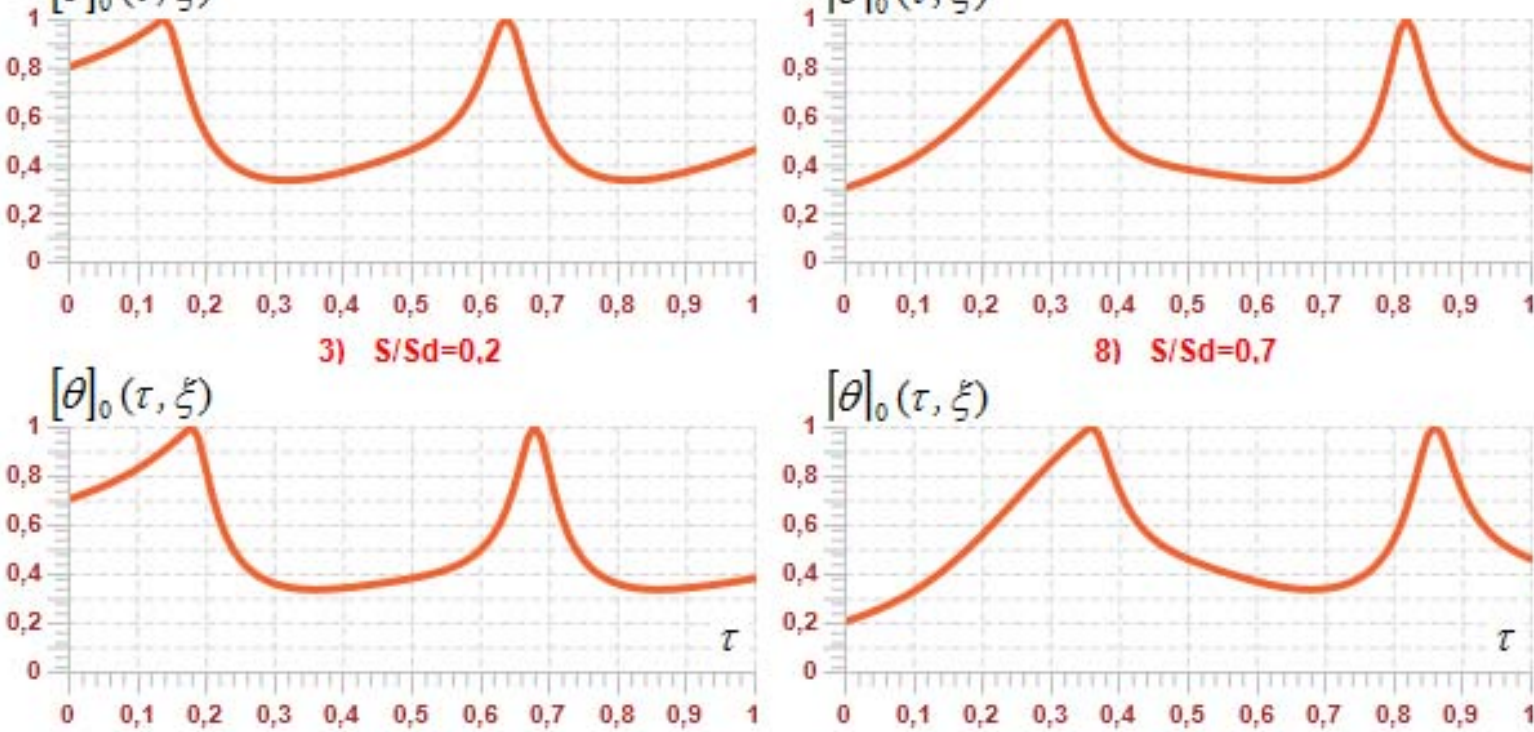

4) $\mathrm{S} / \mathrm{Sd}=0,3$

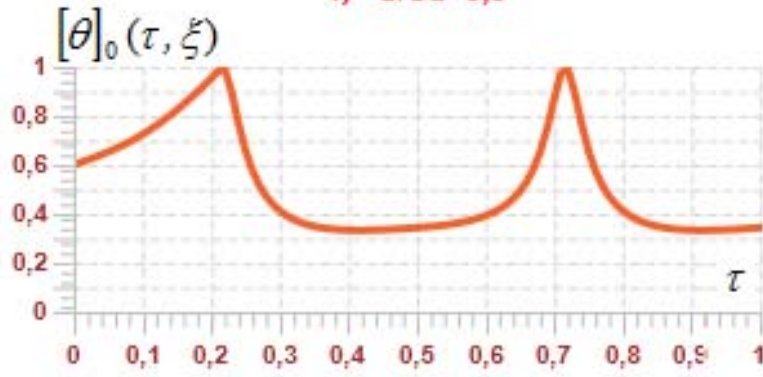

5) $\mathrm{S} / \mathrm{Sd}=0,4$

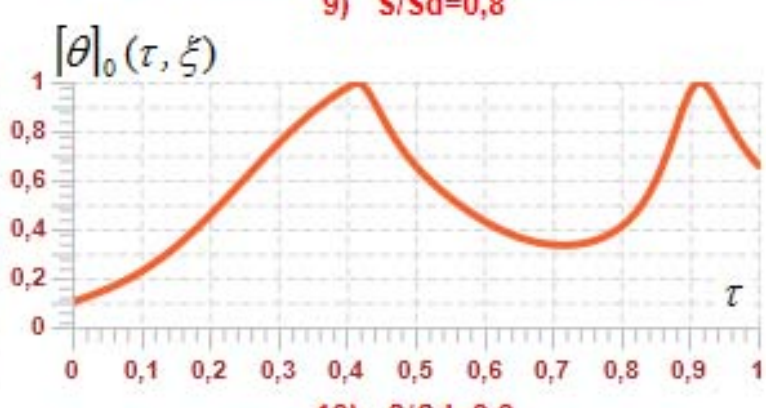

Fig. 6. Detailed representation of the distribution of the rock along the conveyor for the technological position $S=(0,0 ; 0,1 ; 0,2 ; \ldots ; 0,9 ; 1,0)$ 


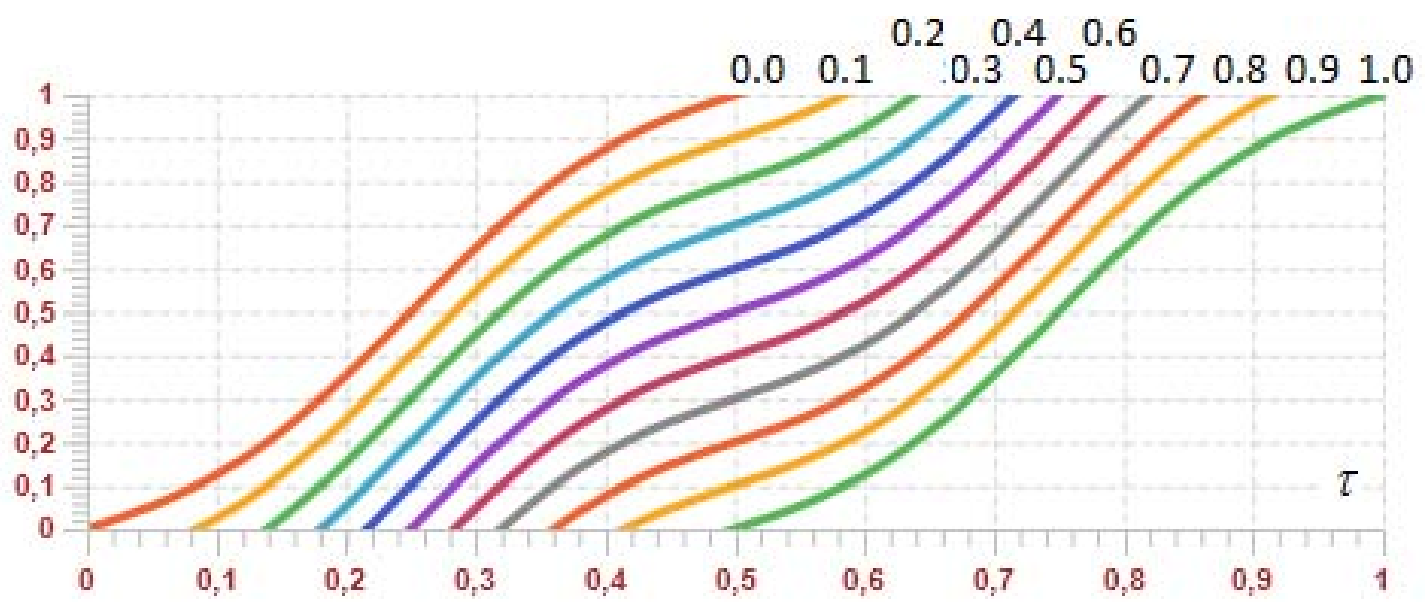

Fig. 7. Family of characteristics

initial and boundary conditions on the parameters of the state of the conveyor line is considered. Along with the advantages in describing complex production systems of flow type, the use of PDE-models is associated with a number of difficulties, one of which is the construction of a closed system of equations of the production process. In this paper, the construction of a closed system of equations is solved by using an additional equation that determines the speed of the conveyor (23). An important result of this work is the method of calculating the duration of the production cycle (29), based on the use of the characteristic equation (24). The duration of the production cycle is not a constant but is determined by the speed of the conveyor belt. A further perspective of the development of the issue discussed in this paper is the construction of a control system for a conveyor line with a variable speed of movement of the belt.

\section{References}

1. Law A.M. Simulation Modeling and Analysis. Boston, McGraw-Hill, 2015.

2. Gross D., Harris C.M. Fundamentals of Queueing Theory. New York, Wiley, 1985.

3. Milling P.M. System Dynamics as a Structural Theory in Operations Management. Production and Operations Management, 2008, vol. 17, no. 3, pp. 373-384.

4. Pihnastyi O.M. [New Class of Dynamic Models Flow Lines of Production System]. Belgorod State University Scientific Bulletin, 2014, no. 31/1, pp. 147-157. (in Russian)

5. Lefeber E. Modeling, Validation and Control of Manufacturing Systems. Proceeding of the 2004 American Control Conference. Massachusetts, 2004, pp. 4583-4588.

6. Armbruster D. Modeling Production Planning and Transient Clearing Functions. Logistics Research, 2012, vol. 87, no. 3, pp. 815-822.

7. Pihnastyi O.M. [Review of Control Models of the Production Lines of the Manufacturing Systems]. Belgorod State University Scientific Bulletin, 2015, no. 34/1, pp. 137-152. (in Russian)

8. Pihnastyi O.M. [Analysis of the Models of Transition Process Controlled Manufacturing]. Belgorod State University Scientific Bulletin, 2015, no. 35/1, pp. 133-144. (in Russian)

9. SIMINE for Conveyors. Siemens. Available at: https://goo.gl/Ku90xp (accessed April 12, 2017). 
10. Semenchenko A., Stadnik M., Belitsky P., Semenchenko D., Stepanenko O. [The Impact of an Uneven Loading of a Belt Conveyor on the Loading of Drive Motors and Energy Consumption in Transportation]. Eastern-European Journal of Enterprise Technologies, 2016, vol. 4, no. 1 (82), pp. 42-51. (in Russian)

11. Kondrahin V., Stadnik N., Belitskii P. [Operating Parameters Statistical Analysis for the Belt Conveyor in Mine]. Donetsk National Technical University Scientific Works, 2013, vol. 2, pp. 140-150. (in Russian)

12. Bambach M., Häck A., Herty M. Modeling Steel Rolling Processes by Fluid-Like Differential Equations. Applied Mathematical Modelling, 2017, vol. 43, pp. 155-169.

13. Prokuda V.N., Mishanskij Ju.A., Procenko S.N. [Research and Evaluation of Cargo Flows on the Main Conveyor Transport of the PSP "Shakhta Pavlogradskaya" PJSC DTEK Pavlogradugol]. Gornaja jelektromehanika i avtomatika, 2012, vol. 88, pp. 107-111. (in Russian)

14. www.bartec.kz (2017). Available at: http://www.bartec.kz/files/mining/for-conveyance.pdf (accessed April 12, 2017).

15. Demutsky V.P., Pihnastyi O.M., Pihnastaja V.S. [Stochastic Description of EconomicProduction Systems with Mass Production]. Reports of the National Academy of Sciences of Ukraine, 2005, vol. 7, pp. 66-71. (in Russian)

16. Pihnastyi O.M., Khodusov V.D. [Calculation of the Production Cycle Using the Statistical Theory of Production Systems]. Reports of the National Academy of Sciences of Ukraine, 2009, vol. 12, pp. 38-44. (in Russian)

Received April 10, 2017

УДК 658.51.012

DOI: $10.14529 / \mathrm{mmp} 170407$

\section{МОДЕЛЬ КОНВЕЙЕРА С РЕГУЛИРУЕМОЙ СКОРОСТЬЮ}

\section{О.М. Пигнастый}

${ }^{1}$ Национальный технический университет «Харьковский политехнический институт», г. Харьков, Украина

${ }^{2}$ Харьковский национальный университет им. В.Н. Каразина, г. Харьков, Украина

Статья посвящена математическому моделированию производственных поточных линий конвейерного типа. Разработан аналитический метод расчета параметров поточной линии с регулируемой скоростью движения предметов труда вдоль конвейера. Описание состояния параметров поточной линии выполнено в одномоментном приближении с использованием уравнений в частных производных. Получено решение, определяющее состояние параметров поточной линии для заданной технологической позиции в виде функции времени. Определена продолжительность переходного периода, в течение которого начальное условие распределения предметов труда вдоль конвейера оказывает влияние на параметры состояния производственной линии. Разработанный метод расчета потоковых параметров производственной линии позволяет проектировать системы управления производственными линии конвейерного типа с регулируемой скоростью движения предметов труда. Оригинальность полученных результатов заключается в улучшении PDE-моделей производственных систем конвейерного типа, используемых для проектирования высокоэффективных систем управления производством.

Ключевые слова: конвейер; производственная линия; предмет труда; поточная линия; РDE-модель производства; параметры состояния поточной линии; технологическая позиция; переходной период; системы управления производством. 


\section{Литература}

1. Law, A.M. Simulation Modeling and Analysis / A.M. Law. - Boston: McGraw-Hill, 2015.

2. Gross, D. Fundamentals of Queueing Theory / D. Gross, C.M. Harris. - New York: Wiley, 1985 .

3. Milling, P.M. System Dynamics as a Structural Theory in Operations Management / A. Grosler, J.H. Thun, P.M. Milling // Production and Operations Management. - 2008. - V. 17, № 3. - P. 373-384.

4. Пигнастый, О.М. О новом классе динамических моделей поточных линий производственных систем / О.М. Пигнастый // Научные ведомости Белгородского государственного университета. - 2014. - № 31/1. - С. 147-157.

5. Lefeber, E. Modeling, Validation and Control of Manufacturing Systems / E. Lefeber, R.A. Berg, J.E. Rooda // Proceeding of the 2004 American Control Conference, Massachusetts. - 2004. - P. 4583-4588.

6. Armbruster, D. Modeling Production Planning and Transient Clearing Functions D. Armbruster, J. Fonteijn, M. Wienke // Logistics Research. - 2012. - V. 87, № 3. P. $815-822$.

7. Пигнастый, О.М. Обзор моделей управляемых производственных процессов поточной линии производственных систем / О.М. Пигнастый // Научные ведомости Белгородского государственного университета. - 2015. - № 34/1. - С. 137-152.

8. Пигнастый О.М. Анализ моделей переходных управляемых производственных процессов / О.М. Пигнастый // Научные ведомости Белгородского государственного университета. - 2015. - № 35/1. - С. 133-144.

9. SIMINE for Conveyors. Siemens. - URL: https://goo.gl/Ku90xp (дата обращения: 12 апреля 2017 г.)

10. Семенченко, А.К. Влияние неравномерности загруженности ленточного конвейера на нагруженность приводных двигателей и энергозатраты на транспортирование / A.K. Ceменченко, Н.И. Стадник, П.В. Белицкий, Д.А. Семенченко, Е.Ю. Степаненко // Восточно-европейский журнал передовых технологий. - 2016. - V. 4, № 1 (82). - С. 42-51.

11. Кондрахин, В.П. Статистический анализ эксплуатационных параметров шахтного ленточного конвейера / В.П. Кондрахин, Н.И. Стадник, П.В. Белицкий // Научные труды Донецкого национального технического университета. - 2013. - № 2/26. - С. 140-150.

12. Bambach, M. Modeling Steel Rolling Processes by Fuid-Like Differential Equations M. Bambach, A. Häck, M. Herty // Applied Mathematical Modelling. - 2017. - V. 43. P. $155-169$.

13. Прокуда, В.Н. Исследование и оценка грузопотоков на магистральном конвейерном транспорте ПСП «Шахта "Павлоградская"» ПАО ДТЭК «Павлоградуголь» / В.Н. Прокуда, Ю.А. Мишанский, С.Н. Проценко // Горная электромеханика и автоматика. - 2012. - № 88. - С. 107-111.

14. www.bartec.kz (2017). - URL: http://www.bartec.kz/files/mining/for-conveyance.pdf (дата обращения: 12 апреля 2017 г.)

15. Пигнастый О.М. Стохастическое описание экономико-производственных систем с массовым выпуском продукции / В.П. Демуцкий, В.С. Пигнастая, О.М. Пигнастый // Доклады Национальной академии наук Украины. - 2005. - Т. 7. - С. 66-71.

16. Пигнастый О.М. Расчет производственного цикла с применением статистической теории производственно-технических систем / О.М. Пигнастый, В.Д. Ходусов // Доклады Национальной академии наук Украины. - 2009. - Т. 12. - С. 38-44. 
Олег Михайлович Пигнастый, доктор технических наук, профессор, кафедра «Компьютерный мониторинг и логистика», Национальный технический университет «Харьковский политехнический институт» (г. Харьков, Украина), pom7@bk.ru.

Валерий Дмитриевич Ходусов, доктор физико-математических наук, профессор, кафедра «Теоретической ядерной физики и высшей математики им. А.И. Ахиезера», Харьковский национальный университет им. В.Н. Каразина (г. Харьков, Украина), khodusov@pht.univer.kharkov.ua.

Поступила в редакиию 10 апреля 2017 г. 